\title{
Latar Belakang Hidup Dan Pendidikan Rabinik Paulus Dalam Kaitannya Dengan Perjumpaannya Dengan Kristus
}

\author{
Robinson Rimun \\ Sekolah Tinggi Teologi Baptis Indonesia Semarang \\ rrimun@yahoo.com
}

\begin{abstract}
ABSTRAK
Paul's historical aspects relating to his background in life and education since childhood have had a great impact on Paul's theological mindset and concepts before and after his conversion. Pauline scholars gave much attention to early education in Tarsus and in Jerusalem which later made Saul a respected rabbi Pharisee. The Apostle Paul, formerly known as Saul of Tarsus, grew up in a Hellenistic environment and used Greek, which was commonly used in the Roman empire. His Hellenistic and Jewish background of life and education became the main emphasis in this article. Saul was radically changed by God after his conversion on the road to Damascus (Acts 9:4); however, this article focuses on Paul's childhood and education in detail in order to understand the Hellenistic and Judaic influence in his theology
\end{abstract}

Kata Kunci: Biblical Theology, Paul, New Testament Study.

\section{PENDAHULUAN}

Israel sebagai sebuah bangsa yang dipilih Allah dan mendapatkan hak-hak istimewa sebagai umat pilihan Allah pada masa Perjanjian Lama menjadikan bangsa Israel sebagai sebuah bangsa yang kuat. Mereka telah mengatur sistem pemerintahan dengan sangat baik sampai menyentuh pada pendidikan dalam keluarga-keluarga bangsa Israel atau bangsa Yahudi. Allah telah memberikan sebuah hukum taurat kepada Musa dan hukum taurat menjadi landasan penting dalam setiap perilaku orang Yahudi pada masa itu. Hukum taurat sebagai sebuah hukum yang mengatur kehidupan mereka harus diajarkan turun temurun kepada anak cucu orang Yahudi dimanapun mereka berada. Maka anak-anak lelaki yang memang mendapatkan perlakukan istimewa pada masa itu harus mendapatkan pendidikan khusus yang tujuan akhirnya diarahkan untuk menjadi seorang rabi yang bertugas

\footnotetext{
${ }^{1}$ John B. Polhill, “Acts,” dalam The New American
Commentary jilid 26 (Nashville, TN: Broadman \&

${ }^{1}$ John B. Polhill, “Acts," dalam The New American
Commentary jilid 26 (Nashville, TN: Broadman \& Holman Publishers, 2001), 457.
}

untuk mengajarkan hukum taurat kepada masyarakat Yahudi lainnya.

\section{PEMBAHASAN}

Dalam Kis. 22, Paulus memberitahukan latar-belakang hidupnya walaupun tidak secara detail. Ia menunjukkan bagaimana kehidupan awalnya yang dalam segala hal adalah seorang Yahudi yang taat. Dia lahir di Tarsus, dibesarkan di Yerusalem, dan dididik di bawah Gamaliel (ayat 3). "Lahir, dibesarkan, dididik" adalah formula biografi yang umum dalam tulisan-tulisan Yunani. Signifikansi hal itu adalah bahwa ketika Paulus menyebut dirinya "dibesarkan" di Yerusalem. Makna yang paling alami adalah bahwa ia dibesarkan sejak kecil di Yerusalem, bukan di Tarsus. Ia nampaknya ke Yerusalem ketika ia masih sangat muda. Ini berhubungan dengan referensi kemudian bahwa keponakannya berada di Yerusalem (Kis. 23:16). ${ }^{1}$

\section{Pendidikan Awal di Tarsus}


Paulus yang lahir di Tarsus ${ }^{2}$ dan menempuh pendidikan awal di sana. Pasti dia belajar keagamaan (Yahudi) dari orang tua dan komunitas Yahudi di Tarsus, tetapi di sana dia juga belajar ilmu pengetahuan yang bersifat helenis. Tarsus adalah sebuah kota komersial yang besar dan makmur yang terletak di Sungai Cydnus, sekitar sepuluh mil dari Laut Mediterania di kaki Pegunungan Taurus di pantai tenggara Asia Kecil. Tarsus terletak 79 meter di atas permukaan laut di dataran timur yang subur daerah Kilikia. Tarsus menjadi ibukota wilayah di bawah kekaisaran Roma. ${ }^{3}$

Menurut ahli geografi Yunani, yaitu Strabo (ca. 63 sM-ad 23), Sungai Cydnus bersumber dari salju mencair dari pegunungan di atas kota. Sungai Cydnus mengalir melalui ibukota kuno ke danau sekitar lima mil ke selatan yang berfungsi sebagai stasiun angkatan laut dan pelabuhan untuk Tarsus. Karena itu Tarsus memiliki kesempatan untuk berkembang menjadi pusat maritim yang maju. Maka tidak ada salahnya ketika Paulus berkata mengenai kota kelahirannya: "Aku adalah orang Yahudi, dari Tarsus, warga dari kota yang terkenal di Kilikia..." (Kis. 21:39). Kota Tarsus terkenal juga karena rute perdagangan utama ke utara melalui Tarsus yang menuju ke Asia. Sifat kosmopolitan kota tersebut sangat membanggakan Paulus, seperti dicatat dalam Kis. 21:39 оuvк

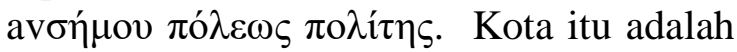
tempat pertemuan Barat dan Timur, dari kebudayaan Yunani dengan mitra orientalnya. $^{4}$

Tidak ada data kapan kota itu dimulai, namun bukti-bukti arkeologi menunjukkan bahwa daerah itu dihuni pada periode Neolitik (kira-kira 5000 sM), dan beberapa kota pada jaman Perunggu (kira-kira 3.000$1.200 \mathrm{sM}$ ) dibangun berturut-turut di situs

\footnotetext{
${ }^{2}$ Pandangan yang umum tentang tempat kelahiran Paulus bertolak-belakang dengan referensi dari Jerome dalam De viris illustribm 5 ketika dia menyebutkan tempat kelahiran Paulus di Palestina, di kota Gischala di Yudea; kemudian orang tuanya membawa serta dia bermigrasi ke Tarsus: "Paul the apostle, previously called Saul, was not one of the Twelve Apostles; he was of the tribe of Benjamin and of the town of Gischala in Judaea; when the town was captured by the Romans he migrated with
}

tersebut. Di pertengahan abad Kesepuluh sebelum Masehi, raja Asyur Salmaneser III menaklukkan Tarsus. Ketika kota itu memberontak pada masa pemerintahan Sanherib, di abad berikutnya kota itu hancur. Tarsus dibangun kembali ketika berada di bawah kendali Persia sampai diambil alih pada tahun 333 sM oleh Alexander Agung yang sempat tinggal di sana untuk waktu yang singkat. Kota ini jatuh ke tangan dinasti Seleukus (312-65 sM) yang berupaya meng-helenisasi penduduknya. Usaha itu memicu suatu pemberontakan melawan Antiokhus IV Epifanes (2 Makabe 4:30). Dengan munculnya kekuatan Roma, wilayah Kilikia diorganisir menjadi sebuah provinsi Romawi dengan Tarsus sebagai ibukotanya. Cicero, orator dan negarawan Romawi, adalah gubernur Tarsus pada tahun 50 sM. Mark Antony memberikan Tarsus status sebagai kota bebas, dan di kota ini ia bertemu dengan Cleopatra pada tahun 41 sM. Kota itu mengalami jaman keemasan dan terkenal sebagai pusat kehidupan intelektual, bahkan melampaui Alexandria dan Athena di bawah pemerintahan Augustus (27 sM-14 M). Tarsus sudah lama menjadi pusat filsafat Stoic, dan beberapa warganya adalah filsuf Stoic yang terkenal seperti: Zeno, Antipater, Athenodorus, dan Nestor. Salah satu prinsip dasar negara Stoicisme adalah "that virtue is the only good as well as the means of fortification against all the pressures of life." Konsep ini tampaknya tercermin dalam beberapa tulisan-tulisan Paulus (misalnya Flp. 4:11-12). ${ }^{5}$

Paulus sebagai Yahudi diaspora menjadi warga negara Romawi, dan sebagai warga dan penduduk asli Tarsus (Kis. 9:11; 21:39, 22:3). Sebagai seorang Yahudi dari Tarsus, Paulus telah dibesarkan di lingkungan non-Yahudi dan berbicara dalam bahasa umum yang dipakai dalam kekaisaran Romawi, yaitu bahasa Yunani. Pengetahuan tentang Kitab Suci Yahudi terutama diperolehnya dari Septuaginta (LXX). ${ }^{6}$

his parents to Tarsus in Cilicia," Jerome MurphyO'Connor, Paul: A Critical Life (Oxford: Oxford University Press, 1997), 37.

${ }^{3}$ Paul J. Achtemeier, Harper's Bible Dictionary (San Francisco, CA: Harper \& Row, 1985), 1018.

${ }^{4}$ Ibid.

${ }^{5}$ Ibid.

${ }^{6}$ Ibid. 
Pembacaan dari LXX menjadi sumber wawasan bagi Paulus dan hampir seluruh surat-suratnya berisi kutipan LXX secara eksplisit. Sebagai warga kota Tarsus, Paulus menempuh pendidikan dasarnya di kota tersebut.

Tentunya di Tarsus ada sekolah dasar bagi anak-anak non-Yahudi dan orang Yahudi yang mulai masuk pada usia 6 tahun. Kedua, sekolah ini melatih muridmurid mereka dengan keterampilan dasar membaca, menulis, dan aritmatika. Sementara itu pada saat yang sama sekolah ini juga menanamkan pengetahuan dan penghormatan terhadap lembaga-lembaga negara dan agama. Sebagai minoritas, anak-anak Yahudi membawa beban yang lebih besar dibandingkan dengan temanteman mereka, karena mereka harus hidup dalam dua dunia, Yahudi dan non-Yahudi. ${ }^{7}$

Paulus, sama seperti murid Yahudi lainnya, harus mempelajari upacara-upacara keagamaan yang merupakan dasar identitas mereka, dimana mereka terikat untuk mematuhinya saat mereka mulai menginjak usia 13 tahun, sebagaimana disebutkan oleh Philo, yang dikutip oleh Jerome MurphyO'Connor:

All men are eager to preserve their own customs and laws, and the Jewish nation above all others; for looking upon theirs as oracles directly given to them by God himself, and having been instructed in this doctrine from their earliest infancy they bear in their souls the images of the commandments. (Philo, Legatio ad Gaium210; trans. Yonge). ${ }^{8}$

Sebagai murid Yahudi di Tarsus, Saulus seharusnya belajar bahasa Aramik dan Ibrani (mungkin di rumah) di samping belajar membaca dan menulis bahasa Yunani. Kurikulum dasar mereka pasti sama dengan kurikulum dasar bagi anakanak non-Yahudi seusia mereka. Selain menggunakan LXX sebagai sumber bacaan, anak-anak Yahudi juga membaca tulisan dari penulis-penulis Yunani seperti

\footnotetext{
${ }^{7}$ Jerome Murphy-O'Connor, Paul: A Critical Life (Oxford: Oxford University Press, 1997), 47.

${ }^{8}$ Ibid.

${ }^{9}$ Murphy-O'Connor, Paul: A Critical Life, 48.
}

Euripides atau Homer. Pelajaran-pelajaran selanjutnya dimulai segera setelah siswa bisa membaca dan menulis dengan mudah, biasanya sekitar usia 11 tahun. Fokus pendidikan helenistik bukanlah pengembangan berpikir kritis, tetapi pada transmisi budaya helenis keseluruhan melalui karya-karya penulis seperti Homer, Euripides, Menander, dan Demosthenes. Ada kemungkinan, murid-murid Yahudi yang ada di wilayah diaspora memberikan perlawanan terhadap aturan yang mengharuskan mereka menerima ide-ide non-Yahudi secara total dari buku-buku pelajaran yang harus mereka pelajari. Sistem pendidikan helenis begitu luas dan metode pengajarannya begitu konsisten, sehingga memastikan orang-orang, bahkan guru-guru Yahudi, dapat ikut dipengaruhi oleh pendidikan mereka. Sebuah sekolah akan melakukan beberapa langkah kritik teks dasar, jika mereka memiliki lebih dari satu naskah penulis klasik dan menemukan perbedaan di antaranya. Ketelitian dan kecermatan pembacaan teks menjadi dasar yang kokoh untuk penafsiran teks, yang diharapkan dapat memberikan kontribusi terhadap perkembangan moral siswa. Seiring dengan pengetahuan murid yang meningkat, mereka mulai berlatih komposisi sastra. ${ }^{9}$

Kualitas pendidikan sekuler Saulus yang kemudian namanya menjadi Paulus terwujud tidak hanya dalam kecakapan berbahasa Yunani, tetapi dalam cara dimana ia mengorganisir isi surat-suratnya. Dia menulis seperti layaknya seorang Yunani yang kuat, yang mengabaikan emosinya karena menyampaikan pemikirannya. Penguasaan sejumlah gaya, dan struktur retoris dari surat-suratnya, dapat menjadi buah penelitian yang serius. Kecakapannya dalam menguasai prinsip presentasi persuasif dengan begitu meyakinkan dapat dilihat dari cara ia berargumentasi dengan orang-orang nonYahudi. ${ }^{10}$

Pada abad Pertama seorang anak Yahudi Palestina menyelesaikan pendidikan wajibnya pada usia 12 atau 13 tahun, yaitu ketika ia secara teknis diterima sebagai orang yang sudah bisa bertanggung jawab. Di lain pihak, sekolah menengah Yunani biasanya ditambah satu atau

\footnotetext{
${ }^{10}$ Jerome Murphy-O'Connor, Paul: His Story (Oxford: Oxford University Press, 2004), 5.
} 
dua tahun lagi. Setelah itu, mereka memasuki pendidikan yang setara dengan universitas saat ini. Pada usia yang dianggap sebagai orang yang dapat bertanggung jawab ini, kemungkinan Saulus telah dikirim ke Yerusalem oleh orang tuanya.

Tidak diketahui dengan pasti apakah Saulus sempat belajar ilmu retorika di Tarsus, di gymnasium misalnya, sebelum kepindahannya ke Yerusalem. ${ }^{11}$ Keterampilan oratoris adalah kunci untuk kemajuan dalam budaya yang dasarnya bersifat verbal. Jika Saulus pernah belajar pendidikan retorika, maka ia akan mengikuti tahapan penguasaan ilmu tersebut. Penguasaan keterampilan tersebut terbagi ke dalam tiga bagian. Dasarnya adalah teori diskursus, termasuk ketrampilan menulis surat. Teknik, aturan, formula, dan sebagainya yang didiskusikan secara ad infinitum. Sebagai penguasaan divisi dan sub-divisi berikutnya, kompleksitas teori menjadi lebih relevan. Tahap kedua adalah sedikit lebih praktis karena melibatkan studi tentang pidatopidato para guru besar dari retorika, yaitu tentang teknik apa yang digunakan, bagaimana mereka menghasilkan dampak, dan bagaimana mereka bisa menjadi lebih baik. Tahap terakhir adalah penulisan pidato yang akan dipraktekkan, dimana untuk sebagian besar topik yang diutamakan adalah kefantastisan daripada hal-hal yang berguna. ${ }^{12}$

Walaupun Paulus tidak secara eksplisit menyebut pendidikan semacam ini, namun dalam surat-suratnya ada indikasi kuat Paulus mempelajari dan memiliki kecakapan retoris. Paulus menggunakan frasa "kai ischyrai" dalam 2 Kor. 10:10. Penyebutan kata sifat tersebut dapat diartikan secara negatif sebagai 'menindas dan berat', namun menurut konsensus para ahli, frasa ini harus

\footnotetext{
${ }^{11}$ Lihat T. R. Glover, Paul of Tarsus (New York: George H. Doran, 1925), 5-23.

${ }^{12}$ Murphy-O'Connor, Paul: A Critical Life, 50. ${ }^{13}$ Ibid.

${ }^{14}$ C. Forbes, "Comparison, Self-Praise and Irony: Paul's Boasting and the Conventions of Hellenistic Rhetoric," New Testament Studies 32 (1986): 22, 4.
}

diterjemahkan secara positif, misalnya 'berbobot dan kuat' atau 'weighty and strong' (RSV), 'mengesankan dan bergerak'. Dengan kata lain, gaya bahasa yang kuat itu diperkuat oleh presentasi dari seorang penulis terlatih. G. A. Kennedy seperti dikutip oleh MurphyO'Connor, menyatakan bahwa:

Paul was 'thoroughly at home in the Greek idiom of his time and in the conventions of the Greek epistles is borne out by the evidence of rhetorical arrangement, not only in the organization of whole letters, but also in the parts of 1 Corinthians when he is dealing with different subjects. ${ }^{13}$

C. Forbes ${ }^{14}$ dan Bernard H. Brinsmead ${ }^{15}$ sangat antusias mendukung pandangan yang menyatakan bahwa Paulus memiliki pendidikan formal yang penuh dalam bidang retorika Yunani, namun Walter B. Russell berargumentasi bahwa hal tersebut telah menembus sistem pendidikan Yahudi. Seperti dikatakan oleh E. A. Judge dalam artikelnya yang berjudul "St. Paul and Classical Society," yang dikutip Russell, menyatakan:

The question of Paul's educational level is probably less clearcut than often thought, but the answer is simpler. It has traditionally been posed in terms of Tarsus or Jerusalem, with the balance now tipped strongly in favour of the latter. But this choice may have set a false trail. To have been brought up in Tarsus need not have committed Paul to a full rhetorical education, let alone a philosophical one (both of which were a matter of tertiary training involving much time and money), while being in Jerusalem need not have excluded him from at least a general acquaintance with the Greek cultural tradition. Half of Gamaliel's pupils are said to have been trained in the wisdom of the Greeks. ${ }^{16}$

Paulus paling tidak mengetahui dan sangat mungkin menguasai tradisi retorika dan filsafat Helenistik, seperti orang-orang Yahudi Diaspora berpendidikan lainnya.

\footnotetext{
${ }^{15}$ Bernard H. Brinsmead, Galatians-Dialogical Response to Opponents, Society of Biblical Literature Dissertation Series 65 (Missoula, MT: Scholars, 1982), 45,6 .

${ }^{16}$ Walter B. Russell, "Rhetorical Analysis of the Book of Galatians, Part 1,” Bibliotheca Sacra 150, no. 199): 345.
} 


\section{Pendidikan Lanjutan di Yerusalem}

Saulus nampaknya adalah seorang anak yang teliti, taat, antusias, dan sangat berbakat, serta sejak awal merasa bahwa ia seharusnya diberikan pendidikan yang terbaik dan menjadi seorang rabi. Untuk sementara keluarga Paulus adalah warga negara Romawi yang setia, mereka juga orang-orang Yahudi saleh dan orang-orang Farisi yang meyakini bahwa studi hukum Yahudi adalah panggilan yang tertinggi. Jadi sejak awal Saulus telah ditentukan untuk belajar menjadi seorang rabi. Tentu saja pusat untuk studi tersebut adalah di Yerusalem, dan Saulus dikirim ke sana untuk belajar. Dalam tahun berikutnya dia memiliki keponakan, anak adiknya, di Yerusalem, dan ia mungkin sudah memiliki seorang saudari yang tinggal dan menikah di sana, dimana ia dapat tinggal, sementara ia menempuh pendidikannya di Yerusalem. ${ }^{17}$

Saulus mengikuti pendidikan rabinik di bawah binaan Gamaliel, seorang rabi terkemuka. Gamaliel adalah cucu Hillel yang terkenal, seorang pemimpin sekolah yang tidak begitu legalistik sehubungan dengan yudaisme dalam hal seperti perceraian, perayaan Sabat, dan hubungan dengan orang kafir. Josephus mulai serius menggeluti pendidikan Farisi pada usia dua puluh tahun, sedangkan Saulus mungkin menggelutinya, ketika ia pergi ke Yerusalem untuk belajar di bawah binaan Gamaliel. ${ }^{18}$

Referensi Perjanjian Baru mengenai pendidikan Paulus di bawah Gamaliel, sebagaimana disebutkan dalam Kisah Para Rasul 22:3 telah sering kali ditantang oleh para sarjana, dengan alasan bahwa suratsuratnya tidak mencerminkan pelatihan formal rabinik. Namun demikian ayat-ayat berikut ini memberi indikasi yang kuat adanya pelatihan yang menyeluruh dan semangat Paulus yang kuat atas hukum Taurat, yakni dalam Gal. 1:14 (кaì

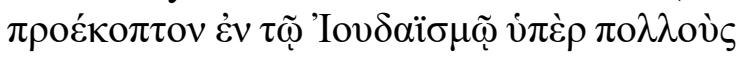
$\sigma 0 v \eta \lambda 1 \kappa i \omega ́ \tau \alpha \varsigma \quad \dot{\varepsilon} v \quad \tau \tilde{\varphi} \quad \gamma \varepsilon \dot{\varepsilon} v \varepsilon 1 \quad \mu 0 v$,

\footnotetext{
${ }^{17}$ Edgar J. Goodspeed, Paul (Philadelphia: John C. Winston, 1947), 10.

${ }^{18}$ Ibid.

${ }^{19}$ Polhill, 457.
}

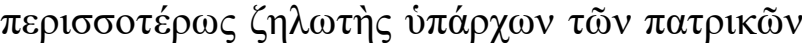

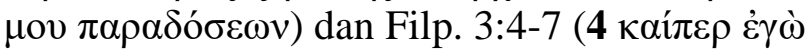

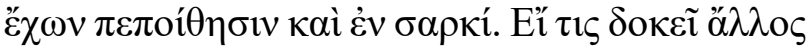

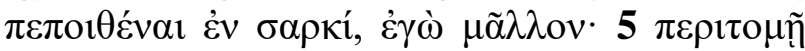

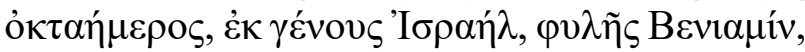

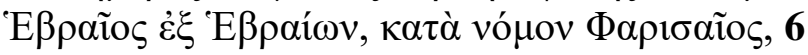

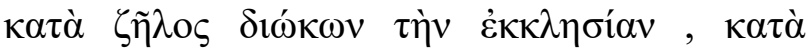

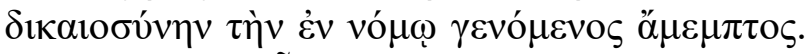

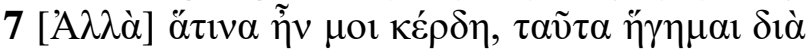

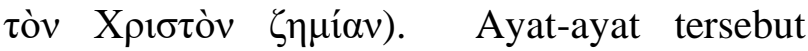
memberi dukungan atas pendidikan kerabian yang diikuti Paulus sebelumnya. ${ }^{19}$

Dalam Galatia 1:14, Paulus berkata: "Dan di dalam agama Yahudi aku jauh lebih maju dari banyak teman yang sebaya dengan aku di antara bangsaku, sebagai orang yang sangat rajin memelihara adat istiadat nenek

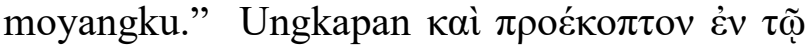

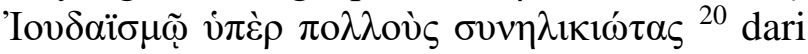
Paulus mengisyaratkan pendidikan resmi Farisi yang digelutinya dengan baik. Prinsip pendidikan Farisi di akhir abad Pertama sM dan abad Pertama Masehi, dapat menjadi referensi pendidikan yang diikuti Paulus.

Murphy-O'Connor memberi pernyataan dari para rabi jaman itu, walaupun ia sendiri mempertanyakan, apakah itu sama dengan sikap kalangan para rabi sebelum atau setelah penghancuran Bait Allah. Catatan tersebut, bagaimanapun, dapat mencirikan tradisi rabinik yang dipelajari dan yang sangat mendasar dari seorang Farisi. Hillel, seorang rabi yang tidak begitu legalistik, dilaporkan mengatakan, "Dia yang tidak belajar [hukum Taurat] layak akan kematian", sedangkan Shammai yang ketat dalam tradisi hanya menasihati, "buatlah [studi] anda akan hukum Taurat menjadi kebiasaan tetap", dan Gamaliel sendiri memberi saran praktis, "provide yourself with a teacher and remove yourself from doubt" (m. Aboth 1. 1316). Anjuran tokoh-tokoh ini paling tidak menggambarkan tradisi terhormat abad Pertama mengenai anjuran untuk belajar. Apalagi, didukung oleh sikap orang Farisi yang membanggakan diri pada ketaatan yang mereka lakukan secara teliti, pengetahuan yang terperinci mengenai perintah-perintah seperti

\footnotetext{
${ }^{20}$ Kurt Aland, The Greek New Testament. 4th ed. (Federal Republic of Germany: United Bible Societies, 1993), 494.
} 
yang tertuang dalam hukum Taurat, baik tertulis maupun lisan. ${ }^{21}$

Ada beberapa pertanyaan yang muncul mengenai masa pendidikan rabinik Paulus, yaitu apakah Paulus tinggal di Yerusalem dari tahun 15 hingga 33 Masehi dan apakah dia pasti berada di kota itu ketika Yesus pergi ke Yerusalem maupun ketika Yesus disalibkan pada tahun $30 \mathrm{M}$. Memang tidak dapat dihindari ada kemungkinan Paulus pernah bertemu dengan Yesus dan atau setidak-tidaknya memiliki pengetahuan langsung tentang penyaliban Yesus. Paulus sendiri bahkan tidak pernah mengisyaratkan adanya pengetahuan atau hubungan semacam itu; ini memunculkan dugaan bahwa Paulus tidak pernah di Yerusalem sebelum pertobatannya atau tiba di sana setelah tahun $30 .{ }^{22}$

\section{Kehidupan Paulus sebagai seorang Rabi}

Setelah melalui proses pendidikan, Saulus menjadi anggota sekte Farisi di Yerusalem. Kisah Para Rasul dan Paulus sendiri membuktikan bahwa dirinya sebagai seorang Farisi (Kis. 23:6, 26:5; Flp. 3:5). Dalam surat-suratnya ia menyebutkan kebanggaan yang dulu ia miliki (eksplisit dalam Flp. 3:3-6 dan implisit dalam Gal. 1:13-14). Sebagai seorang Farisi, Saulus, seperti orang Farisi pada umumnya, memiliki tiga keprihatinan utama: semangat yang tinggi terhadap hukum Taurat, baik tertulis maupun lisan, komitmen terhadap kemurnian Israel, dan keyakinannya tentang kebangkitan tubuh orang mati. Keyakinan tentang kebangkitan tubuh adalah bagian dari kemungkinan suatu pandangan dunia apokaliptik yang lebih luas, yang menyatakan bahwa Tuhan akan mengubah sejarah. ${ }^{23}$

Orang Farisi meyakini bahwa mereka adalah pelindung hukum Taurat, dan bahwa mereka melindungi Israel dari penghakiman ilahi. Arti dari menjaga Israel supaya tetap suci dan murni, serta menjaga

\footnotetext{
${ }^{21}$ Murphy-O'Connor, Paul: A Critical Life, 59.

${ }^{22}$ Ibid., 61.

${ }^{23}$ Michael J. Gorman, Apostle of the Crucified Lord: A Theological Introduction to Paul and His Letters (Grand Rapids, MI: Eerdmans, 2004), 53.
}

dirinya sesuai dengan Hukum Musa, adalah menentang setiap dan semua ancaman terhadap hukum Taurat sehingga terjaga kemurnian etnis dan agama Yahudi. Salah satu dimensi penting dari kegiatan ini adalah melindungi orang-orang Yahudi sehingga terbebas dari kontaminasi orang kafir. Paulus kemudian bisa meringkas sikapnya yang seperti itu dalam Galatia 5:11 untuk menjaga kesucian Israel. ${ }^{24}$

Bagi beberapa orang Farisi, termasuk Paulus, semangat di atas berarti kemungkinan mereka melakukan intimidasi dan bahkan kekerasan terhadap sesama Yahudi yang melanggar hukum, atau ke arah siapa saja yang mengancam kemurnian Israel atau menentang Allah. Paulus juga mengacu pada semangatnya sebagai bagian dari kehidupan awal yudaismenya (Gal. 1:13-14). Ini tidak berarti ia kemudian meninggalkan yudaisme bagi kekristenan. Orang Farisi juga memiliki paham nasionalisme yang ekstrim. Pada abad Pertama, bagi orang Yahudi, politik dan agama tak terpisahkan. Meskipun tidak ada bukti kuat bahwa Paulus merencanakan kekerasan revolusioner melawan Roma, bukanlah hal yang mustahil ia akan mendukung kegiatan yang seperti itu. ${ }^{25}$

\section{Paulus dan Pertobatannya}

Pertobatan Paulus merupakan suatu pengalaman rohani yang luar biasa dialami oleh Paulus. Tidaklah mudah bagi seorang rabi Farisi yang tadinya menentang Yesus Kristus sebagai mesias yang dijanjikan Allah, dan juru selamat dunia.

Paulus berbicara tentang kegiatannya sebelum ia bertobat dalam Gal. 1:13-14. Kekejamannya terhadap agama Kristen ia nyatakan dengan menganiaya orang Kristen. Seperti yang ia katakan: "Sebab kamu telah mendengar tentang hidupku dahulu dalam agama Yahudi: tanpa batas aku menganiaya jemaat Allah dan berusaha membinasakannya" (Gal. 1.13). Frase preposisional $\kappa \alpha \theta$ ' vं $\varepsilon \rho \beta 0 \lambda \eta े v$ yang digunakan Paulus memberi ketegasan ekspresi dari kata keterangan pada derajat yang luar biasa dan pada tingkat ekstrim. Penganiayaan terhadap orang percaya yang

\footnotetext{
${ }^{24}$ Ibid., 53.

${ }^{25}$ Ibid.
} 
dilakukan Paulus memang melebihi melebihi segalanya dari ukuran apapun (bdk: 2 Kor. 4.17). ${ }^{26}$ Komitmennya untuk Yudaisme tidak diragukan lagi. Ia sangat religius ia mengikuti semua hukum dan ketentuan yang berlaku dalam agama Yahudi. Seperti ditegaskannya, кaì

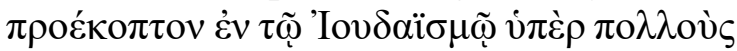

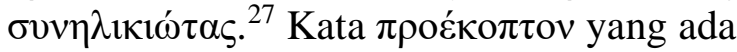
dalam bentuk kata kerja Imperfek aktif orang pertama tunggal mengartikan bahwa Paulus telah mencapai tahap kemajuan yang tinggi dalam ketaatannya sebagai seorang rabi Farisi. D. A. Carson mencatat kegigihan Paulus pada keyakinan lamanya:

Here the apostle points out that his pre-Christian experience was characterized by two features that are incompatible with his present ministry. In the first place, he was fully committed to the persecution of Christians and the extermination of the church (a point detailed for us in Acts 9). Secondly, he was totally devoted to Pharisaism. The expression the traditions of my fathers probably refers not only to the general teachings of Judaism but more specifically to what is otherwise known as the oral law, an extensive set of regulations that distinguished the Pharisees from other Jewish groups (cf. also Mk. 7:1-13; Phil. $3: 4-6)$.

Why does Paul mention these things? A common answer is that they prove Paul did not get his gospel from Jewish teachers. But whoever would have claimed that this is what happened? Certainly not the Judaizers! In a way, this information supports Paul's claim to speak with some authority about the nature of Judaism. It seems likely, however, that these verses are intended less as an independent proof than as a preparation for what he is about to say. In other words, his previous life demonstrates the need he had for a drastic conversion. Only a divine, gracious intervention can explain the change that came over him. ${ }^{28}$

\footnotetext{
${ }^{26}$ Lihat Friberg Timothy, dkk., Analytical Lexicon of the Greek New Testament (Grand Rapids, Mich. : Baker Books, 2000), 390.

${ }^{27}$ Aland, The Greek New Testament, 494.
}

Perjumpaan Paulus dengan Kristus yang telah bangkit dari kematian dalam Kis. 9 menjadi suatu pengalaman yang luar biasa dimana pada saat yang sama ia menerima panggilan sebagai seorang rasul.

Dalam surat Galatia, Paulus memberi penegasan mengenai pertobatannya yang tidak lepas dari rancangan Allah sendiri bagi dia. Ia berkata:

Tetapi waktu Ia, yang telah memilih aku sejak kandungan ibuku dan memanggil aku oleh kasih karunia-Nya, berkenan menyatakan AnakNya di dalam aku, supaya aku memberitakan Dia di antara bangsa-bangsa bukan Yahudi, maka sesaatpun aku tidak minta pertimbangan kepada manusia. ${ }^{29}$

Dia dipilih sebelum ia lahir, dan Yesus Kristus telah menyatakan diri-Nya kepada Paulus. Jadi, kerasulan Paulus itu datang dari Tuhan dan tidak perlu diragukan oleh jemaat Galatia. Perubahan hidup Paulus seperti ditegaskan oleh adalah berfokus pada Kristus.

\section{KESIMPULAN}

Sebagai seorang Yahudi diaspora yang lahir di Tarsus namun dibesarkan di Yerusalem, Paulus mendapatkan pendidikan layaknya anakanak Yahudi pada umumnya. Disebuah kota yang cukup maju secara perekonomian Paulus menempuh pendidikan awal. Pesatnya kemajuan kota Tarsus serta pengaruh helenisme tidak dapat mengalahkan tradisi Yahudi yang sangat mengakar dalam kehidupan orang-orang Yahudi meskipun mereka tinggal di perantauan. Orang Yahudi menganggap pendidikan dasar keagamaan sangat penting sehingga mereka berusaha untuk mendirikan sekolah khusus untuk anak-anak Yahudi di daerah perantauan Sistem helenisme yang begitu kuat masuk kedalam sistem pendidikan sekolah Yahudi di Tarsus, Bahasa Yunani digunakan sebagai Bahasa umum dan situasi ini mendapatkan perlawanan dari orang-orang Yahudi, mereka tidak tinggal diam namun mempertahankan sistem pendidikan Yahudi yang mereka pelihara dengan sangat baik.

Paulus mendapatkan pembelajaran dasar membaca, menulis dan ilmu berhitung sejak usia

\footnotetext{
${ }^{28}$ New Bible Commentary (CD Rom).

${ }^{29}$ Galatia 1:15 dan 16 (TB LAI)
} 
6 tahun. Ilmu dasar yang diimbangi dengan ilmu keagamaan termasuk mempelajari upacara-upacara keagamaan. Doktrin yang kuat ditanamkan kepada Paulus sejak kecil sehingga dia menjadi orang Yahudi fanatik. Namun ada pula dampak positif dalam sistem helenisme pada anak-anak Yahudi termasuk Paulus, nampak pada kemampuan Paulus dalam mengorganisasi isi suratsuratnya. Kemungkinan besar Paulus juga belajar ilmu retorika Yunani mengingat kemampuannya yang cukup baik dalam menulis surat. Meskipun demikian Paulus tetap menunjukkan diri sebagai seorang Yunani yang setia. Sampai usia yang cukup bertanggung jawab Paulus akhirnya dikirim oleh orang tuanya untuk melanjutkan studinya ke Yerusalem.

Pendidikan lanjutan di Yerusalem merupakan sebuah rencana sejak awal yang dibuat oleh orang tuanya bahwa Paulus layak untuk dipersiapkan sebagai seorang rabi, dan Paulus pun juga berpikiran demikian. Seorang guru yang cukup ternama yaitu Gamaliel akhirnya dipilih untuk menjadi gurunya. Paulus menunjukkan kemajuan sangat pesat dibandingkan dengan teman-teman sebaya lainnya. Di Yerusalem, Paulus mulai menerima pendidikan resmi Farisi yang dikuasai dengan cukup baik. karena pendidikan resmi Farisi ini merupakan dasar bagi seorang yang akan menjadi rabi dan harus menguasai hukum taurat dengan baik.

Sebagai seorang Farisi yang taat, Saulus sangat menjaga hukum taurat dan melindunginya dari ancaman orang-orang yang dianggap dapat merusaknya. Serta melindungi orang-orang Israel agar tetap menjalankan hukum taurat sehingga kemurnian etnis dan agama Yahudi dapat terpelihara. Sikap tegas dalam menjaga hukum taurat ditunjukkan oleh Saulus dengan sangat jelas, tegas, dan berani. Namun perjumpaannya dengan Kristus yang telah bangkit dari kematian mengubah keyakinan imannya, sampai akhirnya Paulus menyerahkan hidupnya sebagai Rasul.
DAFTAR PUSTAKA

Polhill, John B., "Acts," dalam The New American Commentary jilid 26, Nashville, TN: Broadman \& Holman Publishers, 2001.

O'Connor, Jerome Murphy, Paul: A Critical Life, Oxford: Oxford University Press, 1997.

Achtemeier, Paul J., Harper's Bible Dictionar, San Francisco, CA: Harper \& Row, 1985.

O'Connor, Jerome Murphy, Paul: His Story, Oxford: Oxford University Press, 2004.

Glover , T. R., Paul of Tarsus, New York: George H. Doran, 1925.

Forbes C., "Comparison, Self-Praise and Irony: Paul's Boasting and the Conventions of Hellenistic Rhetoric," New Testament Studies 32,1986.

Bernard H. Brinsmead, Galatians-Dialogical Response to Opponents, Society of Biblical Literature Dissertation Series 65, Missoula, MT: Scholars, 1982.

Walter B. Russell, "Rhetorical Analysis of the Book of Galatians, Part 1," Bibliotheca Sacra 150, no. 199.

Edgar J. Goodspeed, Paul, Philadelphia: John C. Winston, 1947.

Aland, Kurt, The Greek New Testament. 4th ed., Federal Republic of Germany: United Bible Societies, 1993.

Gorman, Michael J., Apostle of the Crucified Lord: A Theological Introduction to Paul and His Letters, Grand Rapids, MI: Eerdmans, 2004.

Timothy, Friberg, dkk., Analytical Lexicon of the Greek New Testament, Grand Rapids, Mich. : Baker Books, 2000.

Aland, The Greek New Testament.

New Bible Commentary.

Alkitab TB LAI

Soetarman, Seminar Pertumbuhan Gereja (Jakarta: Panitia SPG, 1989) 